Bentham open
CrossMark
Content list available at: www.benthamopen.com/TOBIOTJ/
DOI: $10.2174 / 1874070701610010042$

\title{
Gender and Age Related Modulation of Xenoestrogen-Induced Tumorigenesis
}

\author{
Aleksandra Fucic ${ }^{1, *}$ and Mantovani Alberto ${ }^{2}$ \\ ${ }^{1}$ Institute for Medical Research and Occupational Health, Zagreb, Croatia \\ ${ }^{2}$ Istituto Superiore di Sanità, Roma, Italy
}

\begin{abstract}
Susceptibility to environmental stressors, same as cancer incidence is both age and gender related. Understanding the complexity of responses to living environment has been impaired due to research based on reductionisms and lack of methods, models and sophisticated softwares which enable analysis of complex pathways which may be disturbed by xenobotics. Impact of estrogen on development, maturation and homeostasis of organism in both genders is now well recognised and environmental investigations are currently making major efforts to understand how xenoestrogens affect organisms at very low doses. Additionally, it is of great interest to learn possible synergistic or antagonistic effects of xenoestrogen mixtures on adult organism and during development. The aim of this paper is to review the findings on the association between cancer risk and the endocrine disrupters which directly or indirectly mimic estrogen action.
\end{abstract}

Keywords: Menopausa, puberty, transplacental, tumorigenesis, xenoestrogen.

\section{INTRODUCTION}

Increase of cancer incidence and change in its age and gender distribution during the last few decades can be attributed to better diagnostics but also to exposure to new risk factors [1 - 6], including xenobiotics, introduced to our living environment. Additionally, most investigations and risk assessments did not, or could not, take into account gender and age of subjects at the time of exposure to early risk factors; this knowledge gap on a critical phase of the dynamic of carcinogenesis reduces the accuracy and reliability of current assessments. Thorough investigations on carcinogenesis mechanisms have been carried out at the genome damage level; however, in the last decade research efforts are increasingly redirected towards non-genome levels, including nuclear receptors, glycanes etc; in particular, the interest in the impact of estrogen and xenoestrogens on carcinogenesis has dramatically increased. Recent evidences show that even physical agents such as ionizing radiation may interact with estrogen receptors; moreover, age-related susceptibility is additionally modified by gender showing different susceptibility before and after puberty, pointing out to the role of sex steroids $[5,7]$.

Hormonally active substances are present among biocides, products of combustion, flame retardants, food additives, plasticizers, finishing materials in construction industry etc; therefore, the environmental exposure to hormonemediated tumour-promoting stimuli can be widespread. For instance, the plasticizer Bisphenol A (BPA) has been forbidden in Europe in 2011 for use in baby bottles, but it is still largely used in food and beverage packaging and in thermal papers. Biomonitoring studies have shown a widespread presence of detectable BPA concentrations of BPA in the urine $[8]$ or serum $[9,10]$ in USA and Europe. Moreover, current toxicological tests may not be fully sensitive to detect receptor-mediated effects on developing life stages that lead to increased tumorigenesis later on. The obvious consequences are that regulation of "endocrine disrupting chemicals" (EDC) in environmental settings and diet may not always be based on an adequate scientific basis.

\footnotetext{
* Address correspondence to this author at the Institute for Medical Research and Occupational Health, 10000 Zagreb, Ksaverska c 2, Croatia; Tel: +38514682500; Fax: +38514673303: Email :afucic@imi.hr
} 
Estrogens are the hormones with the strongest evidence of involvement in major human cancers (e.g, of the breast, lung, colon). Current data show that all cancer types are in some way related with the level of estrogen, estrogen receptors and aromatase or their polymorphisms [11 - 14]. Generally estrogen receptor (ER) alpha promotes proliferation, while ER beta supresses it but this is not the rule for all tissues; moreover, the ER status varies between neoplastic tissues. Effect of xenoestrogens on carcinogenesis is not straightforward and depends on tissue distribution of ER alpha and ER beta receptors in target tissue [15 - 17]. Substances with estrogenic actiivity may promote neoplastic changes in specific tissues, as in case of breast and lung cancer [18 - 21]; the case of another major cancer, colorectal cancer, is more difficult. Colon epithelium is rich of ERbeta receptors and an estrogenic action may significantly increase the cancer metastic potency [22]; however, the impacts, whether protective or adverse, of estrogen and estrogen-acrtive substances on cancer promotion are still matter of discussion [23, 24]. Estrogens act as endocrine as well as paracrine and neuromodulator agents, and can affect direct gene transcription, indirect gene transcription and rapid membrane starting signals [25 - 32]. In genomic pathways estrogens exert their function via ER and estrogen response element in the promoter region of estrogen responsive genes. Such pathway usually occurs within hours after activation. Receptor pathways result in cellular responses via cascade of responsive proteins such as protein kinase and transcription factors which regulate cellular processes like proliferation, apoptosis or differentiation. This pathway occurs within minutes after activation [11]. ERs are a complex system of nuclear and cytoplasmic receptors whose levels depend on the tissue type, gender, and stage of development and may change according to estrogen levels. Such diversity and presence in all tissues is a significant part of mammalian adaptability mechanisms but may also pave the way to the action by substances mimicking estrogens. Estrogen action modulates many tissues beyond the reproductive system; indeed, Aljurf et al. [33] pointed out the possible association between estrogen levels and infantile acute lymphoblastic leukemia.

In this paper we will review the findings on the association between cancer risk and the EDC that can (directly or indirectly) mimick estrogen action, the so-called "xenoestrogens".

\section{The Xenostrogens and Cancer Risk}

Xenoestrogens do not act according to physiological timing; thus, compared to endogenous estrogens, xenoestrogens couple with different affinity and have different effect on ER alpha, beta and on G protein-coupled receptor (GPR30) that mediates the rapid response signalling [34, 35]. Due to complex networks -“cross-talks"- of nuclear receptors and different mechanisms of action, xenoestrogens may interact with a number of physiological processes. The complexity of mechanisms related with disruption of estrogen-regulate pathways is shown by dioxins, which affects a plethora of organs and systems, from reproductive to immunological [36]. There is also the possibility of additive (or synergistic) actions as suggested by the combined treatment of embryonic stem cells with the plasticizer bisphenol A and the soy isoflavone genistein [37]. The combined exposure of prepubertal rats to Bisphenol A and genistein increases annexin A2 levels in mammary gland by $73 \%$, whereas genistein alone decreases it by $67 \%$ [8]. It is known that both increased and decreased levels of annexin A2 increase cancer risk [8, 38, 39]. Environmental mixtures of EDC which affect different pathways are difficult to investigate with standard toxicology methods; however, the use of bioinformatics and systems biology may dramatically improve risk assessment of combine exposures [40].

Additionally to xenoestrogens, increased levels of estrogen may be caused by an increased activity of aromatase due to for example consumption of alcohol or may be caused by natural estrogens present in dairy products or phytoestrogens present in food and drinks, the most well-known being the soy isoflavone genistein, and cosmetics (Aloe vera).

The most well-known example of cancer related to environmental xenoestrogens is breast cancer. Many xenoestrogens have been identified as potentially supporting abnormal development of breast epithelial cells, including plasticizers (e.g., bisphenol A), detergent by-products (e.g., o-nonylphenol), pesticides (e.g., permethrin and heptachlor), flame retardants (e.g., polybrominated diphenyl ethers), and a number of toxic trace elements (aluminium, arsenite, cadmium, cobalt, lead, nickel) [41 - 43]. There are little data to assess the actual role of exposure to these chemicals (alone and especially in combination) in the increased incidence of breast cancer in western societies; however, such a role is fully plausible.

The exposure during programming and growth, spurt windows of target organs maybe paramount for increased cancer risk. Higher susceptibility of children to xenobiotics, carcinogens and endocrine disruptors was traditionally related with higher cell division rate, higher exposure doses due to a larger volume of air, water and food which children ingest; recent studies show that prepubertal and pubertal children may express higher susceptibility also due to 
specific endogen hormonal levels during this final period of maturation of most organic systems [7].

Animal models for the investigation of age and gender carcinogenesis are not always reliable due to very demanding interpretation of data and extrapolation to humans. Notwithstanding many interesting experimental data, there are no robust models to test chemicals for increased carcinogenic risks upon developmental (pre- and post-natal) exposures. For instance, little data exist on background levels of hormones and hormone-related receptors during different developmental windows, even for well-known animal breeds.

Individual susceptibility, irrespective of age or gender, is influenced by the frequent polymorphysims of metabolic enzymes and probably also by the less frequent polymorphisms of ERs. Thus, the interaction between the lack of both glutathione S-transpherase (GST) M1 and GSTT1 genes and alcohol consumption significantly increase breast cancer in premenopausal women [44]. Epidemiologic studies have suggested that the exposure to the bioaccumulating pollutants polychlorinated biphenyls (PCBs) increases breast cancer risk in women with $\mathrm{m} 2$ polymorphism in the cytochrome P-450 1A1 gene (CYP1A1); the risk was more elevated in postmenopausal women [45]. Dietary habits may also influence the susceptibility to EDCs, both by modulating exposure (e.g., certain fishing communities are highly exposed to bioaccumulating pollutants) and, most important by modulating the organism's susceptibility through the intake of nutrients and bioactive food components [46]. It could be expected, that in future the carcinogenic risk related to some xenoestrogens will be assessed for population subsets with specific, genetic and/or non-genetic, susceptibility factors

The following chapters will give insight into xenoestrogen effects and mechanisms (as well as on relevant knowledge gaps) during the known critical periods for xenoestrogen activity as carcinogens, namely: transplacental exposure, early infancy, puberty and menopausal period.

\section{Transplacental Exposure to Xenoestrogens and Cancer Risk}

The estrogen balance is involved in the process of mammal development from the very beginning, during the implantation of blastocyst. [47, 48] which explains the recognized implications of xenoestrogens in female and couple infertility problems [49].

Transplacental exposure to xenoestrogens occurs via diet, air and consumer products. Individual lifestyles, including some "health-promoting" behaviour, may further increase the environmental exposures. For instance, the current fashion of food containing whole grains may increase the accumulation of the estrogen-active heavy metal Cadmium in pregnant women due to bioaccumulation of this metal in grains such as durum wheat [50].

The potent non-steroidal synthetic estrogen diethylstilboestrol (DES) has been used as anti-abortion drug in pregnancy during the '60s; the dramatic and unwanted consequence has been the significantly increased risk of reproductive cancers in the daughters, including the rare clear-cell vaginal adenocarcinoma that has represented a sort of "signal" effect. Indeed, diethylstilboestrol represents the paradigm of transplacental carcinogesis due to xenoestrog-ens. An increased level of endogen estrogen and xenoe-strogens is related with cancers of reproductive system in mammals such as (DES), fat diet (which may be at least partly related to increased exposure to bioaccumulating lipophilic xenoestrogens), dairy products which contain cow's estrogen, and internal body burden polychlorinated biphenyls etc [51]. The transplacental exposure to environ-mentally relevant doses of Bisphenol A may cause persistent alterations in mammary gland morphogenesis in female mice, such as increased terminal end bud density at puberty as well as an increased number and lateral branching of terminal ends in adults, which are the sites at which cancer arises in humans and rodents [52]; effects included enhanced sensitivity to estradiol, decreased apoptosis as well as increased number of progesterone receptor-positive epithelial cells at puberty. In sexually mature rats exposed in utero, bisphenol A may directly increase mammary tumours characterised by highly proliferative lesions with increased number of ER-alpha positive cells [53].

Xenoestrogens may not just act on hormone levels. Compounds acting via genomic mechanisms may impact on the methylation levels of genes during transplacental development with potential lifelong effects. In newborn rats exposure to low doses of Bisphenol A $(0.1 \mu \mathrm{g} / \mathrm{kg})$ caused lifelong hypomethylation and increased expression of gene PDE4D4, which regulates a key cell-signalling molecule suggesting that early exposure to xenoesteogens may increase in males predisposition to prostate carcinogenesis [54]. In utero exposure to xenoestrogens has been implicated as contributing factor in the testicular dysgenesis syndrome, characterized by in utero abnormal and deficient masculini-zation of the male reproductive tract, leading to an increased risk of infertility and testicular germ cell tumours in young adults. Although cryptorchidism and family history of testicular cancer are important risk factors for this disease, transplacental and early life exposure to increased levels of endogenous estrogen or xenoestrogens or antiandrogenic factors [51] 
surely play a role. Indeed, rather than simply "low androgen", the shift of estradiol-testostorene balance seems pivotal for abnormal male programming [55]. The syndrome is a public health issue in many industrialized countries, and it leads to poor reproductive capability; the testicular tumours develop from histological alterations during the fetal testis programming, namely, gonocyte foci remaining a pre-invasive carcinoma in situ and, most important, with abnormal epigenetic changes at chromatin level [56]. In addition, one should not think to environmental exposures only. In vitro experiment on human fetal testis showed that analgesics inhibiting insulin-like factor 3 ; this change would increase the risk of cryptorchidism which is known to be a component of testicular dysgenesis syndrome as well as a risk factor for testicular cancer [57].

The metabolic response of adult organism to xenobiotics can be disturbed by xenoestrogens as estrogen regulates development of primate fetal liver [58]; therefore, xenoestrogens can indirectly alter the metabolism in adulthood of carcinogenic chemicals by interfering with normal development of liver. In human fetal liver specimens Bisphenol A treatment altered the maturation of specific phase I and II metabolizing genes via epigenetic mechanisms [59]. Fetal liver has high levels of metallothionein [60]; in case of high mother's exposure, the newborn may have significant concentrations in liver of cadmium, a metal with xenoestrogen activity, which is also related with increased cancer risk [61]. Transplacental exposure to cadmium also causes shortening of telomeres which is a known risk factor for cancer development $[43,62]$.

\section{Xenoestrogen Exposure and Cancer Risk in Newborns and Toddlers}

During the first two years of life human metabolism and clearance are in a transient form, with a gradual maturation from the fetal to the adult metabolic capacity $[63,64]$. Infants need to consume more water, food and breathe more air per body mass than adults, and in the meanwhile their detoxification capacity and kidney clearance are lower than in adults [65]. Additionally, newborns have an undeveloped immune system, which may reduce the ability to cope with cancer cells, and their body composition is different than in adulthood.

Due to short latency period, cancers which occur during the two first years of life are likely a consequence of transplacental exposure, although direct infant exposure may also contribute. Bioaccumulated xenobiotics in fetal intestine after birth can be redistributed and their levels in tissues can be increased during the neonatal period [66]. In newborns the skin barrier is not fully developed and compounds from personal care products can be transdermally absorbed more than in adults. Many personal care products still contain as additives or ingredients xenobiotics that can act as xenoestrogens, like parabens (especially butyl- and propyl-) used as preservants [67, 68] and the UV-filtering agent methyl benzylidene camphor [69]. Products for newborns also may contain extracts from plants containing phytoestrogens such as the phytosterol-rich Aloe vera [70].

On the other hand, exposures during early infancy might be important for the onset of tumours in childhood. Although the cancer survival rate has significantly increased, over the past 30 years the incidence of children diagnosed with all forms of invasive cancer has increased from 11.5 cases per 100,000 children in 1975 to 14.8 per 100,000 children in 2004, i.e., more than 25\% National Cancer Institute, USA; [71]. During this vulnerable period of life the most frequent cancer types are acute lymphoblastic leukemia and to a lesser extent, brain tumors. Both cancers show gender specific incidence: females are at a lower risk than males for both [72].

Leukaemia alone account for about $31 \%$ of all cancers in children. The most common types in children are acute lymphocytic leukemia (ALL) and acute myelogenous leukaemia (AML). A recent meta-analysis commissioned by the European Food Safety Authority (http://www.efsa.-europa.eu/it/supporting/doc/497e.pdf) showed that the environmental exposure to pesticides is significant associated with increased risk of childhood leukaemia. However, the available data do not allow identifying with certainty the pesticide chemical groups that are associated with this effect nor the mechanisms involved or the susceptible life stage windows. Some indications pointing to insecticides (e.g., organophosphates, pyrethroids) may deserve further investigations. An in vitro study on TK6 human lymphoblastoid cell line has shown that estrogen causes DNA rearrangements within the hot spot of the MLL breakpoint cluster [73] which suggests the possibility that xenoestrogens may take part in transplacental induction of infant leukaemia. High levels of maternal soy consumption have been linked with the development of both ALL and AML [74, 75]. Infants drinking soy-based formula have the highest exposure levels to phytoestrogens in the population: if the soy formula is the only source of nutrition during their first few months of life, serum concentrations are 10-fold greater than in adult vegetarians.

Brain and central nervous system tumors are the second most common cancers in children, making up about $21 \%$ of 
childhood cancers. Most brain tumors in children start in the lower parts of the brain, such as the cerebellum or brain stem. About $7 \%$ of childhood cancers are neuroblastomas, originating from the embryonic forms of nerve cells. EDC with different mechanisms, such as di(2-ethylhexyl) phthalate (DEHP) (an inhibitor of steroid biosynthesis) and the xenoestrogen BPA may both promote invasion and metastasis of neuroblastoma cells, indicating that different EDC pathways may lead to similar outcomes [76]. Although, reports on the possible correlations between xenoestrogens and brain tumors are scares, hormonal therapy by estrogen agonists is applied for gliomas in small children; thus an involvement of xenoestrogens in the pathogenesis might deserve some attention.

Whereas in utero exposures might be highly relevant risk factors for the development of childhood cancers, the neonatal and early infancy life stage should be also regarded as a susceptible window where the newborns and toddlers may experience specific high exposures, though baby foods, personal care products, toys, etc. Rodent studies show that early life exposure may have lifelong consequences; thus, altered programming may occur also after birth. Exposure of rats on 10-12 postnatal days to BPA and genistein caused epigenetic programming in the uterus which is related to tumorigenesis but via different pathways, namely both BPA and genistein act via nuclear receptor-mediated, i.e. "genomic", signalling while only genistein acts via rapid membrane-starting signalling. This difference may be explained by different affinity to both ERs and by different tuning of epigenetic signalling [77]. Neonatal exposure to low doses of DES in mice causes obesity in adulthood which is a risk factor for breast cancer [78]. Thus, xenoestrogens might increase cancer risk also through indirect effect on metabolism and growth during early life.

\section{Susceptibility to Xenoestrogens During Prepuberty and Puberty}

Puberty is not characterised by any specific type of cancer and, indeed, cancer is relatively rare in this age group. However, successful final maturation of all organ systems in this period of life is of comparable significance as the fetal period as it is a vestibule which may lead to healthy life and reproduction or towards increased risks of diseases, sterility and premature aging.

According to the "estrogen window hypothesis", breast cancer risk is related to estrogen exposure during puberty [79]. Obesity and earlier age of puberty are major factors in the recently reported increase of breast cancer in younger women [6] and may both be related to prepubertal and peripubertal exposure to EDC [7, 80].

Air pollution is described as a mixture of xenoestrogens. High exposure to traffic emissions at the time of menarche was associated with a possible increased risk of premenopausal breast cancer, although the increase was slightly below statistical significance (OR 2.05, 95\% CI 0.92-4.54) [81]. A large (more than 1800 breast cancer patients who had resided in the same cities for at least 10 years prior to their diagnosis) Chinese study showed that patients living in highpollution areas had a younger age at menarche, a greater family history of breast cancer and more invasive cancers, with higher tumor grades and estrogen receptor ER-positive status [82]. Thus, the available data support a role in breast cancer risk for traffic pollution exposure during puberty and adolescence; however, the data do not identify which (groups of) compounds are main drivers of the tumorigenic effect.

Transplacental exposure to xenoestrogens enhanced responses to estrogen in the mammary tissue of pubertal mice [83]; it could be suggested that xenoestrogen exposure during puberty might also provide a further input to the carcinogenesis process in breast tissue where early programming was already altered. Most important, puberty itself represents a specific susceptible window. Pubertal exposure of mice to low-doses of BPA increased hyperplasia in adult mammary glands and caused an acute increase of mammary stem cells in adulthood. Deep sequencing analysis in mammary stem cell-enriched mammospheres identified a set of aberrantly expressed genes associated with early neoplastic lesions in patients with human breast cancer [84]. Greater susceptibility to genome damage in pre-pubertal as compared to adult BALB/CJ mice was also reported for the xenoestrogen diethylstilbestrol [85].

Testicular germ cell tumor is a cancer observed during or immediately after puberty, which incidence dramatically increased during the last decades. As we already discussed, altere transplacental programming is the critical step. However, xenoestrogen exposure during puberty (with its dramatic endocrine changes) may also play a role in the multi-step process of testicular carcinogenesis; alkylphenols (detergent by-products able to act as ER-agonists) do trigger a rapid, ERa36-PI3kinase pathway, which, in its turn, can modulate the expression of the DNAmethyltransferase-3 (Dnmt3) gene family which is involved in DNA methylation control, a mechanism suggested to play a role in testicular cancer [86]. It is noteworthy that, when investigating dietary risk factors, testicular cancer was significantly related with transplacental (maternal) and prepubertal consumption of cheese [87]. Milk is a source of both endogenous ruminant estrogens and lipophilic xenostrogens, the latter becoming much more concentrated in cheese and 
other dairy products.

Higher urinary BPA concentrations in girls in age of 10-13 years are associated with hypomethylation of genes involved in immune function and caspase activity, which might suggest a reduced ability to cope with cancer cells [88].

A Flemish biomonitoring studies in adolescents (14-15 years) showed that the correlations between biomarkers of exposure to xenoestrogens and biomarkers of hormone status may be somewhat less straightforward than previously thought. Serum levels of testosterone, estradiol and aromatase index were positively associated with serum levels of highly persistent, non-dioxin-like polychlorobi phenyls (congeners 138, 153, and 180) and of another highly persistent EDC, hexachlorobenzene; estradiol also showed a positive association with the DDT metabolite DDE. Conversely, the same parameters showed a negative association with urinary cadmium concentration [89]. It may be noteworthy that both the investigate PCB and hexachlorobenzene are mainly CYP modulators, that may affect liver metabolism of hormones. The study highlighted the need to interpret biomonitoring data through a thorough toxicological knowledge, especially in critical population groups such as adolescents and children.

\section{Menopause (and Andropause)}

The menopausal and andropausal periods are characterised by significant increases in all cancer types in both genders' except for some types such as testicular cancer and some leukemias, which are more typical of younger ages. Cancer incidence have different male-to-female incidence rate and this difference is diminishing with increasing age based on data of Surveillance, Epidemiology and End Results Programme (http://seer.cancer.gov-/csr/ 1975_2011/sections.html). The reason for decreasing of gender related difference in cancer incidence is because menopause/andropause is a declining period of life characterised by decrease in estrogen and androgen levels in women and men respectively, opposite to puberty when such gender differences appears. During menopausal/andropausal stage, major cancer types are breast cancer in women and prostate cancer in men, i.e., two clearly hormone-dependent tumours. The incidence of both cancer types correlates and depends on diet and lifestyle [90].

Exposure to xenoestrogens in menopausal period represents a condition which is contrary to the natural process of aging, as the organism is changing its physiology to adapt to low levels of estrogen and testosterone. Prolongation of exposure to xenoestrogen may have effect on ER levels and is not tuning with other process occurring in the organism such as DNA repair etc. Menopause is also characterised by change in diet and behaviour. Cultural models in industrialized societies push to keep younger; men and women usually start to use herbal drugs or cosmetics in order to improve skin complexion or reduce feeling of tiredness. As already mentioned this can be a significant source of xenostrogens as well as of phytoestrogens extracted from soya, Aloe vera, flax, tofu etc. During andropause/menopause, after a lifelong making up of pollutants body burden, gender differences in the bioaccumulation of xenobiotics may become obvious [91]. Such differences are based on physiology as well as on behaviour and culture, even in industrialized countries with high level of gender equality, many families do willingly follow a rather traditional role division, where men are overall more exposed to traffic and workplace pollution and women are more exposed to household products (e.g, cleansing agents) and personal care products.

However, post-menopausal breast cancer represent a major estrogen-relate cancer. In postmenopausal period estrogen levels in breast tissue may be several times higher than in blood due to aromatization of androgens within organs. As estrogen metabolites are carcinogenic, this phenomenon may lead to cancer development [11]. The cancer risk may be modulated by metabolic polymorphisms. Increased risk of breast cancer in women exposed to polychlorinated biphenyls was highest in carriers of CYP1A1 m2 variant genotype, especially for those women who were in postmenopausal period [45]. Interestingly, the risk of breast cancer is lower in women who had children and did breast feed them; this protective effect of breast feeding in mothers may occur at the expense of the newborns, as milk is an effective way to excrete fat soluble xenoestrogens, thus reducing the maternal body burden. The highest pollutant excretion occurs at the lactation of the first baby [92].

Living near factories generating polycyclic aromatic hyrocarbons and dioxins is a major risk factor in premenopausal breast cancer [93]: both pollutant groups are agonists of the aryl hydrocarbon receptor, which has complex cross-talk with ERs and other steroid receptors. Thus, residence and past occupational exposure leading to a pollutant body burden should be considered also in postmenopausal breast cancer.

\section{CONCLUSION}

Current evidences show significant molecular biological differences between age groups within the same cancer 
types which on one side demands specific therapy approach but also questioned our models of investigation of their aetiology [94 - 97] ; different age susceptibility may be related to higher mitotic potency of cells in young age or lower repair capacity in older age, but they could have origin also in disturbance of complex interactions of hormonal, genetic and epigenetic cross roads specific for each stage of life, and with additional gender-specific aspects. The dramatic gender-specific endocrine changes of puberty or the long term impact of lifelong body burden in old age are telling examples. Xenoestrogens have obviously much lower affinity than endogenous estrogens for ERs. This fact is so obvious that is surprising that is still used as an argument to discount concerns about EDC health effects, just ignoring numbers of evidences in humans and wildlife as well [98]. The sheer facts are that xenoestrogens:

a. Can impinge on physiological processes, modulating and deviating pathways orchestrated by endogenous estrogens. This may occur during life stage windows requiring close endocrine control; the susceptibility to EDC is not equal throughout life

b. Produce estrogen-like stimuli outside the physiological control and tuning of the endocrine network control of the organism

c. May act in an additive way by hitting the same tissue targets, although the molecular mechanisms and chemical structure would be different, as pointed by the European Food Safety Authority with regard to the cumulative effects of pesticides $[99,100]$ may exert effects through mechanisms that are different from the traditional ERrelated pathways, i.e., rapid membrane receptor-related pathways or gender- and age-relate epigenetic modulation [101].

Indeed, the epigenetic effects of xenoestrogens may be the most urgent data gap. Impact of xenoestrogens on methylation disturbances during development with lifelong effects is well described for several organs and organ systems [102, 103] but data on related cancer risks are still limited, although a link is obviously plausible. Robust methods to screen and assess the impact of chemicals on epigenetic modulation are also urgently needed [104].

While beginning of $20^{\text {th }}$ century was marked with struggle of women for social equality proving equality in all segments of life except reproduction, the beginning of $21^{\text {st }}$ century marked scientific proof of the diversity between men and women with regards to responses towards environmental stimuli; this is bringing significant changes in medicine, as, e.g., a drug may be metabolized in quite different, sex-related ways, but also in the environmental and food sectors.

In fact, regulations on pollutants should take into account new scientific evidences on age and gender differential susceptibilities $[105,106]$.

Oncology during the last decade recognized the significance of estrogen and testosterone in treatment of cancer types which were not traditionally defined as hormonally related. In the same time, recent evidences point to the need for redefinition of endocrine disruptors as hormonally active carcinogens. Thus, an improved collaboration between environmental health experts and oncologists may in future bring to both fields significant added value.

\section{CONFLICT OF INTEREST}

The authors confirm that this article content has no conflict of interest.

\section{ACKNOWLEDGEMENTS}

Study was fundedwithin the frame of the EU LIFE project LIFE EDESIA (http://www.issit/life) and Croatian Ministry of Science, Education and Sport.

\section{REFERENCES}

[1] Znaor A, Lortet-Tieulent J, Jemal A, Bray F. International variations and trends in testicular cancer incidence and mortality. Eur Urol 2014; 65(6): 1095-106.

[http://dx.doi.org/10.1016/j.eururo.2013.11.004]

[2] Znaor A, van den Hurk C. Cancer incidence and mortality patterns in South Eastern Europe in the last decade: gaps persist compared with the rest of Europe. Eur J Cancer 2013; 49(7): 1683-91. [http://dx.doi.org/10.1016/j.ejca.2012.11.030]

[3] Carter D. New global survey shows an increasing cancer burden. Am J Nurs 2014; 114(3): 17 [http://dx.doi.org/10.1097/01.NAJ.0000444482.41467.3a]

[4] Sankaranarayanan R, Ramadas K, Qiao YL. Managing the hanging burden of cancer in Asia. BMC Med 2014; $12: 3$. [http://dx.doi.org/10.1186/1741-7015-12-3] 
[5] Fucic A, Gamulin M. Environmental exposure to xenoestrogens and oestrogen related cancers: reproductive system, breast, lung, kidney, pancreas, and brain. Environ Health 2012; 11(Suppl1): S8. [http://dx.doi.org/10.1186/1476-069X-11-S1-S8]

[6] Merlo DF, Ceppi M. Breast cancer incidence trends in European women aged 20-39 years at diagnosis. Breast Cancer Res Treat 2012; 134(1): $363-70$ [http://dx.doi.org/10.1007/s10549-012-2031-7]

[7] Mantovani A, Fucic A. Puberty dysregulation and increased risk of disease in adult life: possible modes of action. Reprod Toxicol 2014; 44: $15-22$.

[http://dx.doi.org/10.1016/j.reprotox.2013.06.002]

[8] Betancourt AM, Wang J, Jenkins S, et al. Altered carcinogenesis and proteome in mammary glands of rats after prepubertal exposures to the hormonally active chemicals bisphenol a and genistein. J Nutr 2012; 142: 1382S-8S. [http://dx.doi.org/10.3945/jn.111.152058]

[9] Caserta D, Bordi G. The influence of endocrine disruptors in a selected population of infertile women. Gynecol Endocrinol 2013 ; 29 : $444-7$. [http://dx.doi.org/10.3109/09513590.2012.758702]

[10] Caserta D, Ciardo F, Bordi G, et al. Correlation of endocrine disrupting chemicals serum levels and white blood cells gene expression of nuclear receptors in a population of infertile women. Int J Endocrinol 2013; 2013: 510703 [http://dx.doi.org/10.1155/2013/510703]

[11] Chen GG, Zeng Q, Otse GM. Estrogen and its receptors in cancer. Med Res Rev 2008; 28(6): 954-74. [http://dx.doi.org/10.1002/med.20131]

[12] Zhang J, Yin Y. CYP19A1 gene polymorphisms and risk of lung cancer. J Int Med Res 2013; 41(3): 735-42. [http://dx.doi.org/10.1177/0300060513477291]

[13] Li L, Zhang X, Xia Q, Ma H, Chen L, Hou W. Association between estrogen receptor alpha PvuII polymorphism and prostate cancer risk. Tumour Biol 2014; 35(5): 4629-35. [http://dx.doi.org/10.1007/s13277-014-1606-9]

[14] Thomas C, Gustafsson JA. The different roles of ER subtypes in cancer biology and therapy. Nat Rev Cancer 2011; 11(8): 597-608. [http://dx.doi.org/10.1038/nrc3093]

[15] Gallo D, De Stefano I, Prisco GM, Scambia G, Ferrandina G. Estrogen receptor beta in cancer: an attractive target for therapy. Curr Pharm Des 2012; 18(19): 2734-57. [http://dx.doi.org/10.2174/138161212800626139]

[16] Dey P, Barros RP, Warner M, StrAöm A, Gustafsson JA. Insight into the mechanisms of action of estrogen receptor I in the breast, prostate, colon, and CNS. J Mol Endocrinol 2013; 51(3): T61-74. [http://dx.doi.org/10.1530/JME-13-0150]

[17] (a) Nilsson S, Gustafsson JA. Estrogen receptors: therapies targeted to receptor subtypes. Clin Pharmacol Ther 2011; 89(1): 44-55. [http://dx.doi.org/10.1038/clpt.2010.226] ; (b) Warner M, Gustafsson JA. The role of estrogen receptor I (ERI ) in malignant diseases ?"A new potential target for antiproliferative drugs in prevention and treatment of cancer. Biochem Biophys Res Commun 2010; 396(1): 63-6. [http://dx.doi.org/10.1016/j.bbrc.2010.02.144]

[18] Hartman J, StrAöm A, Gustafsson JA. Estrogen receptor beta in breast cancer--diagnostic and therapeutic implications. Steroids 2009; 74(8): 635-41. [http://dx.doi.org/10.1016/j.steroids.2009.02.005]

[19] Fernandez SV, Russo J. Estrogen and xenoestrogen in breast cancer. Toxicol Pathol 2010; 38(1): 110-22. [http://dx.doi.org/10.1177/0192623309354108]

[20] Darbre PD, Charles AK. Environmental oestrogens and breast cancer: evidence for combined involvement of dietary, household and cosmetic xenoestrogens. Anticancer Res 2010; 30(3): 815-27.

[21] Fucic A, Gamulin M, Ferencic Z, et al. Lung cancer and environmental chemical exposure: a review of our current state of knowledge with reference to the role of hormones and hormone receptors as an increased risk factor for developing lung cancer in man. Toxicol Pathol 2010; 38(6): 849-55.

[http://dx.doi.org/10.1177/0192623310378136]

[22] Foster P. Oestrogen and colorectal cancer: mechanisms and controversies. Int J Colorectal Dis 2013; 28(6): 737-49. [http://dx.doi.org/10.1007/s00384-012-1628-y]

[23] Brandstedt J, Wangefjord S, Nodin B, et al. Associations of hormone replacement therapy and oral contraceptives with risk of colorectal cancer defined by clinicopathological factors, beta-catenin alterations, expression of cyclin D1, p53, and microsatellite-instability. BMC Cancer 2014; $14: 371$ [http://dx.doi.org/10.1186/1471-2407-14-371]

[24] Marino M. Xenoestrogens challenge 17ß-estradiol protective effects in colon cancer. World J Gastrointest Oncol 2014; 6(3): 67-73.

[25] Thomas C, Gustafsson JA. The different roles of ER subtypes in cancer biology and therapy. Nat Rev Cancer 2011; 11(8): 597-60. [http://dx.doi.org/10.1038/nrc3093] 
[26] Marino M, Pellegrini M, La Rosa P, Acconcia F. Susceptibility of estrogen receptor rapid response to exenoestrogens: physiological outcomes. Steroids 2012; 77(10): 910-7. [http://dx.doi.org/10.1016/j.steroids.2012.02.019]

[27] Marino M, Ascenzi P. Membrane association of estrogen receptor alpha and beta influences 17beta-estradiol-mediated cancer cell proliferation. Steroids 2008; 73(9-10): 853-8. [http://dx.doi.org/10.1016/j.steroids.2007.12.003]

[28] Hammes SR, Levin ER. Minireview: Recent advances in extranuclear steroid receptor actions. Endocrinologogy 2011; 152(12): 4489-95. [http://dx.doi.org/10.1210/en.2011-1470]

[29] Levin ER. Minireview: Extranuclear steroid receptors: roles in modulation of cell functions. Mol Endocrinol 2011; 25(3): $377-84$. [http://dx.doi.org/10.1210/me.2010-0284]

[30] Levin ER. Plasma membrane estrogen receptors. Trends Endocrinol Metab 2009; 20(10): 477-82. [http://dx.doi.org/10.1016/j.tem.2009.06.009]

[31] Ascenzi P, Bocedi A, Marino M. Structure-function relationship of estrogen receptor alpha and beta: impact on human health. Mol Aspects Med 2006; 27(4): 299-402. [http://dx.doi.org/10.1016/j.mam.2006.07.001]

[32] Kerdivel G, Habauzit D, Pakdel F. Assessment and molecular actions of endocrine disrupting chemicals that interfere with estrogen receptor pathways. Int J Endocrinol 2013; 2013: 501851 [http://dx.doi.org/10.1155/2013/501851]

[33] Aljurf M, Saleh AJ, Ahmed SO. MLL gene in maternal and infantile acute lymphoblastic leukemia and the effect of Estrogen. Leuk Res 2011; 35(7): e127.

[http://dx.doi.org/10.1016/j.leukres.2011.02.013]

[34] Hall JM, Korach KS. Analysis of the molecular mechanisms of human estrogen receptors alpha and beta reveals differential specificity in target promoter regulation by xenoestrogens. J Biol Chem 2002; 277(46): 44455-61. [http://dx.doi.org/10.1074/jbc.M200849200]

[35] Safe S, Papineni S. The role of xenoestrogenic compounds in the devleopment of breast cancer. Trends Pharmacol Sci 2006; $27(8): 447-54$. [http://dx.doi.org/10.1016/j.tips.2006.06.006]

[36] Birnbaum LS, Fenton SE. Cancer and developmental exposure to endocrine disruptors. EHP 2003; 111(4): $389-94$. [http://dx.doi.org/10.1289/ehp.5686]

[37] Kong D, Xing L. Individual and combined developmental toxicity assessment of bisphenol A and genistein using the embryonic stem cell test in vitro. Food Chem Toxicol 2013; 60: 497-505. [http://dx.doi.org/10.1016/j.fct.2013.08.006]

[38] Huang Y, Jin Y, Yan C, et al. Involvement of Annexin A2 in p53 induced apoptosis in lung cancer. Mol Cell Biochem 2008; 309(1-2): 117-23.

[http://dx.doi.org/10.1007/s11010-007-9649-5]

[39] Zhang X, Liu S, Guo C, Zong J, Sun MZ. The association of annexin A2 and cancers. Clin Trans1 Oncol 2012; 14(9): 634-40. [http://dx.doi.org/10.1007/s12094-012-0855-6]

[40] Junker A, Sorokin AA, Czauderna T, Schreiber F, Mazein A. Wiring diagrams in biology: towards the standardized representation of biological information. Trends Biotechnol 2012; 30(11): 555-7.

[http://dx.doi.org/10.1016/j.tibtech.2012.08.003]

[41] Rudel R, Camann D, Spengler J, Korn L, Brody J. Phthalates, alkylphenols, pesticides, polybrominated diphenyl ethers, and other endocrinedisrupting compounds in indoor air and dust. Environ Sci Technol 2003; 37: 4543-53. [http://dx.doi.org/10.1021/es0264596]

[42] Brody J, Rudel R. Environmental pollutants and breast cancer. Environ Health Perspect 2003; 111: $1007-19$. [http://dx.doi.org/10.1289/ehp.6310]

[43] Darbre PD. Environmental oestrogens, cosmetics and breast cancer. Best Pract Res Clin Endocrinol Metab 2006; 20(1): $121-43$. [http://dx.doi.org/10.1016/j.beem.2005.09.007]

[44] Park SK, Yoo KY. Alcohol consumption, glutathione S-transferase M1 and T1 genetic polymorphisms and breast cancer risk. Pharmacogenetics 2000; 10(4): 301-9. [http://dx.doi.org/10.1097/00008571-200006000-00004]

[45] Zhang Y, Wise JP. Serum polychlorinated biphenyls, cytochrome P-450 1A1 polymorphisms, and risk of breast cancer in Connecticut women. Am J Epidemiol 2004; 160(12): 1177-83.

[http://dx.doi.org/10.1093/aje/kwh346]

[46] Baldi F, Mantovani A. A new database for food safety: EDID (Endocrine disrupting chemicals - Diet Interaction Database). Ann Ist Super Sanita 2008; 44: 57-63.

[47] Vasquez YM, DeMayo FJ. Role of nuclear receptors in blastocyst implantation. Semin Cell Dev Biol 2013; 24(10-12): 724-35. [http://dx.doi.org/10.1016/j.semcdb.2013.08.004] 
[48] Hou Q, Paria BC, Mui C, Dey SK, Gorski J. Immunolocalization of estrogen receptor protein in the mouse blastocyst during normal and delayed implantation. Proc Natl Acad Sci USA 1996; 93(6): 2376-81. [http://dx.doi.org/10.1073/pnas.93.6.2376]

[49] Caserta D, Mantovani A. Environment and women's reproductive health. Hum Reprod Update 2011; 17: 418-33. [http://dx.doi.org/10.1093/humupd/dmq061]

[50] Harris NS, Taylor GJ. Cadmium uptake and partitioning in durum wheat during grain filling. BMC Plant Biol 2013; 13 : 103. [http://dx.doi.org/10.1186/1471-2229-13-103]

[51] Giannandrea F, Paoli D, FigA -Talamanca I, Lombardo F, Lenzi A, Gandini L. Effect of endogenous and exogenous hormones on testicular cancer: the epidemiological evidence. Int J Dev Biol 2013; 57(2-4): 255-63. [http://dx.doi.org/10.1387/ijdb.130015fg]

[52] Munoz-de-Toro M, Markey CM. Perinatal exposure to bisphenol-A alters peripubertal mammary gland development in mice. Endocrinology 2005; 146(9): 4138-47. [http://dx.doi.org/10.1210/en.2005-0340]

[53] Murray TJ, Maffini MV, Ucci AA, Sonnenschein C, Soto AM. Induction of mammary gland ductal hyperplasias and carcinoma in situ following fetal bisphenol A exposure. Reprod Toxicol 2007; 23(3): 383-90. [http://dx.doi.org/10.1016/j.reprotox.2006.10.002]

[54] Prins GS, Tang WY, Belmonte J, Ho SM. Developmental exposure to bisphenol A increases prostate cancer susceptibility in adult rats: epigenetic mode of action is implicated. Fertil Steril 2008; 89(2 Suppl): e41. [http://dx.doi.org/10.1016/j.fertnstert.2007.12.023]

[55] Veeramachaneni DN, Klinefelter GR. Phthalate-induced pathology in the foetal testis involves more than decreased testosterone production. Reproduction 2014; 147(4): 435-42. [http://dx.doi.org/10.1530/REP-13-0441]

[56] Vega A, Baptissart M, Caira F, et al. Collection 2012. Epigenetic: a molecular link between testicular cancer and environmental exposures. Front Endocrinol (Lausanne) 2012; 29(3): 150.

[57] Mazaud-Guittot S, Nicolaz CN. Paracetamol, aspirin, and indomethacin induce endocrine disturbances in the human fetal testis capable of interfering with testicular descent. J Clin Endocrinol Metab 2013; 98(11): E1757-67.

[http://dx.doi.org/10.1210/jc.2013-2531]

[58] Rosenthal MD, Albrecht ED, Pepe GJ. Estrogen modulates developmentally regulated gene expression in the fetal baboon liver. Endocrine 2004; 23(2-3): 219-28. [http://dx.doi.org/10.1385/ENDO:23:2-3:219]

[59] Nahar MS, Kim JH, Sartor MA, Dolinoy DC. Bisphenol A-associated alterations in the expression and epigenetic regulation of genes encoding xenobiotic metabolizing enzymes in human fetal liver. Environ Mol Mutagen 2014; 55(3): $184-95$. [http://dx.doi.org/10.1002/em.21823]

[60] Clough SR, Mitra RS, Kulkarni AP. Qualitative and quantitative aspects of human fetal liver metallothioneins. Biol Neonate 1986; 49(5): 241-54. [http://dx.doi.org/10.1159/000242538]

[61] Nawrot T, Plusquin M. Environmental exposure to cadmium and risk of cancer: a prospective population-based study. Lancet Oncol 2006; 7(2): 119-26. [http://dx.doi.org/10.1016/S1470-2045(06)70545-9]

[62] Lin S, Huo X, Zhang Q. Placental telomere was associated with cadmium pollution in an electronic waste recycling town in china. PLoS One 2013; 8(4): e60815. [http://dx.doi.org/10.1371/journal.pone.0060815]

[63] Scheuplien R, Charnley G, Dourson M. Differential sensitivity of children and adults to chemical toxicity: i. biological basis. Regul Toxicol Pharmacol 2002; 35(3): 429-47. [http://dx.doi.org/10.1006/rtph.2002.1558]

[64] DeWoskin RS, Thompson CM. Renal clearance parameters for PBPK model analysis of early lifestage differences in the disposition of environmental toxicants. Regul Toxicol Pharmacol 2008; 51(1): 66-86. [http://dx.doi.org/10.1016/j.yrtph.2008.02.005]

[65] Ono H, Sakamoto A, Sakura N. Plasma total glutathione concentrations in healthy pediatric and adult subjects. Clin Chim Acta 2001; 312: 227-9. [http://dx.doi.org/10.1016/S0009-8981(01)00596-4]

[66] Scheuplein R, Charnley G, Dourson M. Differential sensitivity of children and adults to chemical toxicity. Regul Toxicol Pharmacol 2002; 35: 429-47. [http://dx.doi.org/10.1006/rtph.2002.1558]

[67] Darbre PD, Harvey PW. Paraben esters: review of recent studies of endocrine toxicity, absorption, esterase and human exposure, and discussion of potential human health risks. J Appl Toxicol 2008; 28(5): 561-78. [http://dx.doi.org/10.1002/jat.1358] 
[68] Yoo YM, Choi KC, Jeung EB. Potential estrogenic effect(s) of parabens at the prepubertal stage of a postnatal female rat model. Reprod Toxicol 2010; 29(3): 306-16. [http://dx.doi.org/10.1016/j.reprotox.2010.01.013]

[69] Durrer S, Ehnes C, Fuetsch M, et al. Estrogen sensitivity of target genes and expression of nuclear receptor co-regulators in rat prostate after pre- and postnatal exposure to the ultraviolet filter 4-methylbenzylidene camphor. Environ Health Perspect 2007; 115(Suppl1): 42-50.

[70] Palermo FA, Cocci P, Angeletti M, et al. Dietary Aloe vera components' effects on cholesterol lowering and estrogenic responses in juvenile goldfish. Carassius auratus. Fish Physiol Biochem 2013; 39(4): 851-61. [http://dx.doi.org/10.1007/s10695-012-9745-7]

[71] Siegel R, Naishadham D, Jemal A. Cancer statistics. CA Cancer J Clin 2012; 62(1): 10-29. [http://dx.doi.org/10.3322/caac.20138]

[72] Sareddy GR, Nair BC. Therapeutic significance of estrogen receptor I agonists in gliomas. Mol Cancer Ther 2012; 11(5): 1174-82. [http://dx.doi.org/10.1158/1535-7163.MCT-11-0960]

[73] Schnyder S, Du NT, Le HB, Singh S, Loredo GA, Vaughan AT. Estrogen treatment induces MLL aberrations in human lymphoblastoid cells. Leuk Res 2009; 33(10): 1400-4. [http://dx.doi.org/10.1016/j.leukres.2009.01.023]

[74] Azarova AM, Lin RK, Tsai YC, Liu LF, Lin CP, Lyu YL. Genistein induces topoisomerase IIbeta- and proteasome-mediated DNA sequence rearrangements: Implications in infant leukemia. Biochem Biophys Res Commun 2010; 399(1): 66-71. [http://dx.doi.org/10.1016/j.bbrc.2010.07.043]

[75] Hengstler JG, Heimerdinger CK. Dietary topoisomerase II-poisons: contribution of soy products to infant leukemia? EXCLI J 2002; 1: 8-14 .

[76] Zhu H, Zheng J, Xiao X, et al. Environmental endocrine disruptors promote invasion and metastasis of SK-N-SH human neuroblastoma cells 2010 .

[77] Greathouse KL, Bredfeldt T, Everitt JI, et al. Environmental estrogens differentially engage the histone methyltransferase EZH2 to increase risk of uterine tumorigenesis. Mol Cancer Res 2012; 10(4): 546-57. [http://dx.doi.org/10.1158/1541-7786.MCR-11-0605]

[78] Newbold RR, Padilla-Banks E, Snyder RJ, Jefferson WN. Developmental exposure to estrogenic compounds and obesity. Birth Defects Res A Clin Mol Teratol 2005; 73(7): 478-80. [http://dx.doi.org/10.1002/bdra.20147]

[79] Korenman SG. The endocrinology of breast cancer. Cancer 1980; 46(4 Suppl): 874-8 [http://dx.doi.org/10.1002/1097-0142(19800815)46:4+<874::AID-CNCR2820461305>3.0.CO;2-\#]

[80] Maranghi F, Mantovani A. Targeted toxicological testing to investigate the role of endocrine disrupters in puberty disorders. Reprod Toxicol 2012; 33(3): 290-6.

[http://dx.doi.org/10.1016/j.reprotox.2012.01.009]

[81] Nie J, Beyea J. Exposureto traffic emissions throughout life and risk of breast cancer: the Western New York Exposures and Breast Cancer (WEB) study. Cancer Causes Control 2007; 18(9): 947-55. [http://dx.doi.org/10.1007/s10552-007-9036-2]

[82] Huo Q, Zhang N, Wang X, Jiang L, Ma T, Yang Q. Effects of ambient particulate matter on human breast cancer: is xenogenesis responsible? PLoS One 2013; 8(10): e76609. [http://dx.doi.org/10.1371/journal.pone.0076609]

[83] Wadia PR, Vandenberg LN, Schaeberle CM, Rubin BS, Sonnenschein C, Soto AM. Perinatal bisphenol A exposure increases estrogen sensitivity of the mammary gland in diverse mouse strains. Environ Health Perspect 2007; 115(4): 592-8. [http://dx.doi.org/10.1289/ehp.9640]

[84] Wang D, Gao H. Pubertal bisphenol A exposure alters murine mammary stem cell function leading to early neoplasia in regenerated glands. Cancer Prev Res (Phila) 2014; 7(4): 445-55. [http://dx.doi.org/10.1158/1940-6207.CAPR-13-0260]

[85] Fucic A, Stojkovic R. Animal model for age- and sex-related genotoxicity of diethylstilbestrol. Braz J Med Biol Res 2009; $42(11)$ : 1090-6.

[86] Ajj H, Chesnel A, Pinel S, Plenat F, Flament S, Dumond H. An alkylphenol mix promotes seminoma derived cell proliferation through an ERalpha36-mediated mechanism. PLoS One 2013; 8(4): e61758. [http://dx.doi.org/10.1371/journal.pone.0061758]

[87] Ganmaa D, Li XM, Wang J, Qin LQ, Wang PY, Sato A. Incidence and mortality of testicular and prostatic cancers in relation to world dietary practices. Int J Cancer 2002; 98(2): 262-7. [http://dx.doi.org/10.1002/ijc.10185]

[88] Kim JH, Rozek LS. A-associated epigenomic changes in prepubescent girls: a cross-sectional study in Gharbiah, Egypt. Environ Health 2013; 12: 33 . [http://dx.doi.org/10.1186/1476-069X-12-33]

[89] Dhooge W, den Hond E. Internal exposure to pollutants and sex hormone levels in Flemish male adolescents in a cross-sectional study: associations and dose-response relationships. J Expo Sci Environ Epidemiol 2011; 21(1): 106-13. 
[http://dx.doi.org/10.1038/jes.2009.63]

[90] Coffey DS. Similarities of prostate and breast cancer: evolution, diet and estrogens. Urology 2001; (Suppl 4A):31-8. [http://dx.doi.org/10.1016/S0090-4295(00)00938-9]

[91] Arbuckle TE. Are there sex and gender differences in acute exposure to chemicals I the same setting? Environ Res 2006; 101: 195-204. [http://dx.doi.org/10.1016/j.envres.2005.08.015]

[92] Fernandez MF, Molina-Molina JM. Biomonitoring of environmental estrogens in human tissues. Int J Hyg Environ Health 2007; 210(3-4): 429-32. [http://dx.doi.org/10.1016/j.ijheh.2007.01.014]

[93] Bidgoli SA, Eftekhari T, Sadeghipour R. Role of xenoestrogens and endogenous sources of estrogens on the occurrence of premenopausal breast cancer in Iran. Asian Pac J Cancer Prev 2011; 12(9): 2425-30.

[94] Collinson K, Murray MJ, Orsi NM, et al. Age-related biological features of germ cell tumors. Genes Chromosomes Cancer 2014; 53(3): $215-27$. [http://dx.doi.org/10.1002/gcc.22131]

[95] Gilheeney SW, Kieran MW. Differences in molecular genetics between pediatric and adult malignant astrocytomas: age matters. Future Oncol 2012; 8(5): 549-58.

[http://dx.doi.org/10.2217/fon.12.51]

[96] MasquA(c)-Soler N, Szczepanowski M. Absence of BRAF mutation in pediatric and adolescent germ cell tumors indicate biological differences to adult tumors. Pediatr Blood Cancer 2012; 59(4): 732-5. [http://dx.doi.org/10.1002/pbc.24005]

[97] Deffenbacher KE, Iqbal J. Molecular distinctions between pediatric and adult mature B-cell non-Hodgkin lymphomas identified through genomic profiling. Blood 2012; 119(16): 3757-66. [http://dx.doi.org/10.1182/blood-2011-05-349662]

[98] Nohynek GJ, Borgert CJ, Dietrich D, Rozman KK. Endocrine disruption: fact or urban legend? Toxicol Lett 2013; 223(3): $295-305$. [http://dx.doi.org/10.1016/j.toxlet.2013.10.022]

[99] Scientific Opinion on the identification of pesticides to be included in cumulative assessment groups on the basis of their toxicological profile. EFSA J 2013; 11(7): 3293.

[http://dx.doi.org/10.2903/j.efsa.2013.3293]

[100] Relevance of dissimilar mode of action and its appropriate application for cumulative risk assessment of pesticides residues in food. EFSA J 2013; 11(12): 3472 [http://dx.doi.org/10.2903/j.efsa.2013.3472]

[101] Huen K, Yousefi P. Effects of age, sex, and persistent organic pollutants on DNA methylation in children. Environ Mol Mutagen 2014; 55(3): $209-22$ [http://dx.doi.org/10.1002/em.21845]

[102] Wolstenholme JT, Rissman EF, Connelly JJ. The role of Bisphenol A in shaping the brain, epigenome and behavior. Horm Behav 2011; 59(3): 296-305 [http://dx.doi.org/10.1016/j.yhbeh.2010.10.001]

[103] Meunier L, Siddeek B. Perinatal programming of adult rat germ cell death after exposure to xenoestrogens: role of microRNA miR-29 family in the down-regulation of DNA methyltransferases and Mcl-1. Endocrinology 2012; 153(4): 1936-47. [http://dx.doi.org/10.1210/en.2011-1109]

[104] Greally JM, Jacobs MN. In vitro and in vivo testing methods of epigenomic endpoints for evaluating endocrine disruptors. ALTEX 2013; 30(4): 445-71

[http://dx.doi.org/10.14573/altex.2013.4.445]

[105] Fucic A, Gamulin M. Environmental exposure to xenoestrogens and oestrogen related cancers: reproductive system, breast, lung, kidney, pancreas, and brain. Environ Health 2012; 11(Suppl1): S8 [http://dx.doi.org/10.1186/1476-069X-11-S1-S8]

[106] Fucic A, Gamulin M. Lung cancer and environmental chemical exposure: a review of our current state of knowledge with reference to the role of hormones and hormone receptors as an increased risk factor for developing lung cancer in man. Toxicol Pathol 2010; 38(6): 849-55. [http://dx.doi.org/10.1177/0192623310378136]

Received: May 31, 2014 Revised: April 20, 2015 Accepted: June 5, 2015

(C) Fucic and Alberto; Licensee Bentham Open

This is an open access article licensed under the terms of the Creative Commons Attribution-Non-Commercial 4.0 International Public License (CC BY-NC 4.0) (https://creativecommons.org/licenses/by-nc/4.0/legalcode), which permits unrestricted, non-commercial use, distribution and reproduction in any medium, provided the work is properly cited. 